\title{
РОЛЬ НАВЧАЛЬНО-ПРАКТИЧНИХ ЦЕНТРІВ ПЕРВИННОЇ МЕДИКО- САНІТАРНОЇ ДОПОМОГИ В ПІДГОТОВЦІ СТУДЕНТІВ ТА ІНТЕРНІВ ДО РОБОТИ В ПЕРВИННІЙ ЛАНЦІ ОХОРОНИ ЗДОРОВ'Я
}

Н. I. Ярема

ДВНЗ “Тернопільський державний медичний університет імені І. Я. Горбачевського МОЗ України”

\section{A ROLE OF PRIMARY HEALTH CARE EDUCATIONAL - PRACTICAL CENTERS IN TRAINING OF STUDENTS AND INTERNS TO WORK IN PRIMARY LINK OF PUBLC HEALTH}

\author{
N. I. Yarema \\ SHEI "Ternopil State Medical University by I. Ya. Horbachevsky of MPH of Ukraine”
}

\begin{abstract}
Автори статті діляться досвідом навчання студентів та інтернів сімейної медицини на базах навчально-практичних центрів первинної медико-санітарної допомоги, створених у сільській місцевості.

The authors of the article share their experience teaching the students and interns of Family Medicine at the bases of educational-practical centers of primary health care which are created in rural areas.
\end{abstract}

Вступ. Тернопільський медичний університет став центром реформування системи охорони здоров'я свого регіону - вже кілька років над цим працюють його фахівці, а головне - готують кадри з прицілом на майбутнє. Перші реальні кроки вже зроблено відкрито п'ять сільських навчально-практичних центрів у різних районах області. Це унікальний для України досвід, адже сільська медицина - найуразливіша ланка нашої системи охорони здоров'я [1-3].

Процес реформування системи охорони здоров'я вимагає не лише відповідного матеріально-технічного, кадрового, інформаційного, а й науково-методичного $\mathrm{i}$ педагогічного забезпечення. Постає питання підготовки фахівців, які за рівнем знань змогли б у повному обсязі надати первинну медичну допомогу населенню. 3 цією метою у Тернопільському державному медичному університеті імені І. Я. Горбачевського за ініціативи ректора чл.-кор. НАМН України, проф. Л. Я. Ковальчука було створено систему навчально-практичних центрів первинної медико-санітарної допомоги у сільській місцевості Тернопільської області [4].

Основна частина. У Тернопільській області більш як тисяча сіл. Свого часу медичний університет звернувся до місцевої влади -піднімаймо сільську медицину разом. Відгукнулися, на жаль, тільки троє сільських голів. Коли відкрилися перші центри, від охочих не стало відбою.
Новітня форма реального практичного навчання студентів випускних курсів нашого університету та лікарів-інтернів здійснюється у цих новостворених навчально-практичних центрах первинної медико-санітарної допомоги (НПЦПМСД). Такі центри організовані в селах Зарубинці Збаразького району, Гнилиці Підволочиського району, Великий Говилів Теребовлянського району, Увисла та Кокошинці Гусятинського району. У них студенти та інтерни перебувають, як правило, протягом тижня, що дає змогу ознайомитись $з$ реаліями сільської медицини та набути навичок надання медичної допомоги жителям області різного віку, залучити майбутніх спеціалістів до роботи в сільській місцевості.

НПЦПМСД є навчальним підрозділом ДВНЗ “Тернопільський державний медичний університет імені I. Я. Горбачевського”, який забезпечує проведення навчальних і профілактичних заходів з метою попередження та зменшення захворюваності, раннього виявлення хворих, а також диспансеризацію та надання первинної медичної допомоги населенню.

Практичне навчання студентів 6-го курсу та лікарівінтернів у навчально-практичних центрах первинної медико-санітарної допомоги здійснюється за графіками деканатів медичного факультету, стоматологічного факультету та факультету післядипломної освіти ТДМУ ім. І. Я. Горбачевського, затвердженими 
проректором із науково-педагогічної та лікувальної роботи, в яких передбачені терміни практичного навчання та фіксовані години амбулаторного прийому хворих, подворових обходів і надання профілактичної та іншої роботи.

Один раз на тиждень, а при потребі і частіше, в НПЦПМСД виїжджають викладачі - спеціалісти клінічних кафедр ТДМУ, які проводять спеціалізовані консультативні прийоми жителів цих сіл. Лікарі-інтерни разом зі штатними працівниками лікувально-профілактичних закладів при необхідності направляють пацієнтів у лікувально-профілактичні заклади другого рівня та у Тернопільську університетську лікарню.

НПЦПМСД оснащені типовим обладнанням: стоматологічною установкою сучасного зразка, електрокардіографом з можливістю дистанційної передачі електрокардіограми в Тернопільську університетську лікарню, небулайзером, комп'ютером із встановленою програмою "Реєстратура" та "Skype”, мобільним зв”язком та мережею “Інтернет”. Студенти та лікарі-інтерни можуть отримати консультацію у відеорежимі on-line з провідними спеціалістами Тернопільської університетської лікарні. Для студентів та лікарів-інтернів створено найкращі побутові умови: житловий блок зі всіма зручностями, індивідуальне опалення, наявність супутникового телебачення.

Основними завданнями діяльності НПЦПМСД є надання першої та невідкладної лікарської допомоги хворим при гострих та несподіваних захворюваннях, травмах, отруєннях та нещасних випадках; надання лікарської допомоги вдома людям, котрі за станом здоров'я та характером захворювання не можуть відвідати амбулаторії чи перебувають на ліжковому режимі; профілактичні огляди і диспансерний нагляд за хворими, комплексні профілактичні заходи серед населення, спрямовані на зниження захворюваності, інвалідності та смертності; участь в організації та забезпеченні диспансеризації населення, здорових та хворих підлітків, осіб із підвищеним ризиком онкологічних, серцево-судинних та інших захворювань, заходи щодо санітарно-гігієнічного навчання населення, пропаганди здорового способу життя, у тому числі раціонального харчування, боротьби із курінням та іншими шкідливими звичками.

Студенти та лікарі-інтерни тісно співпрацюють 3 сімейними лікарями амбулаторій загальної практики - сімейної медицини та фельдшерами ФАПів, що дозволяє їм побачити реалії роботи в сільській місцевості, відчути потребу в сімейних лікарях на селі.

У жовтні 2010 року відбулося урочисте відкриття перших навчально-практичних центрів первинної ме- дико-санітарної допомоги у с. Зарубинці Збаразького району на базі медичного пункту поруч з музеємсадибою І. Я. Горбачевського та у с. Гнилиці Підволочиського району на базі ФАПу. У церемонії відкриття взяли участь голова Тернопільської обласної державної адміністрації, ректор ДВНЗ “Тернопільський державний медичний університет імені І. Я. Горбачевського" чл.-кор. НАМН України, проф. Л. Я. Ковальчук, начальник Головного управління охорони здоров’я Тернопільської облдержадміністрації М. М. Буртняк, голови Підволочиської райдержадміністрації та районної ради. 3 січня 2011 року НПЦПМСД працює у с. Великий Говилів Теребовлянського району, який відкрито на базі ФАПу.

У листопаді 2011 року відбулося урочисте відкриття навчально-практичних центрів первинної медикосанітарної допомоги в селі Увисла, який розташований на базі амбулаторії загальної практики - сімейної медицини та у селі Кокошинці Гусятинського району. Ця подія стала логічним продовженням ініціативи ректора нашого університету щодо удосконалення надання медичної допомоги сільському населенню Тернопільської області.

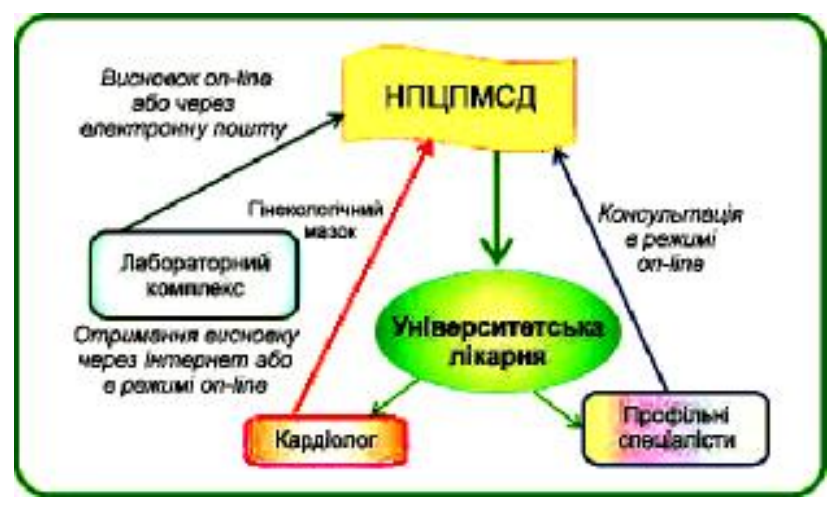

Передача ЕКГ та гінекологічних мазків 3 НПЦПМСД в університетську лікарню та міжкафедральну наукову-клінічну лабораторію через Інтернет і отримання висновку кардіоло-

га та іниих спеціалістів в режимі оn-line

Під час проведення розширеної колегії МO3 України, яка проводилась в м. Тернополі 16-17 липня 2012 року, НПЦПМСД відвідав заступник міністра охорони здоров'я О. Толстанов. За результатами ознайомлення 3 діяльністю НПЦПМСД заступник міністра дав схвальну оцінку здобуткам університету, зокрема рівнем освоєння практичних навичок студентами та інтернами ТДМУ. Особливо високу оцінку з уст заступника міністра отримали знання студентів та інтернів телекомунікаційних та комп'ютерних технологій, які будуть використовува- 
тись у практичній діяльності майбутніх сімейних лікарів.

Таким чином, тепер наш університет забезпечив стабільну можливість навчати всіх студентів випускних курсів медичного та стоматологічного факультетів, а також лікарів-інтернів у новостворених центpax. Для майбутніх лікарів - це чудова можливість випробувати свої сили, розібратися в тому, що добре засвоїли, а над чим слід ще попрацювати, коли повернуться до навчання. Величезним плюсом $є$ безцінний досвід спілкування з пацієнтами, коли студент чи лікар-інтерн отримав можливість самостійно приймати рішення, нести за це відповідальність. Після такої практики випускники не боятимуться села, бо переконуються, що і тут можуть бути створені нормальні умови для роботи та проживання.

У 2013 році будуть організовуватись навчальнопрактичні центри медичного університету на базі

\section{Література}

1. Концепція розвитку ДВНЗ “Тернопільський державний медичний університет імені І. Я. Горбачевського МО3 України" на 2013-2017 pp. - Тернопіль : Укрмедкнига, 2013. $-79 \mathrm{c}$.

2. Ковальчук Л. Без університетських лікарень неможливо реформувати медицину / Л. Ковальчук // Дзеркало тижня. Україна. - 2012. - № 4. - 3 лютого. амбулаторій загальної практики - сімейної медицини у місті Тернополі, в яких разом з сімейними лікарями лікувальних комунальних закладів міста силами викладачів університету буде надаватись медична допомога жителям відповідних мікрорайонів міста i проводитиметься навчальна практика студентів i лікарів-інтернів Тернопільського державного медичного університету ім. І. Я. Горбачевського, щоб вони проходили повноцінне практичне навчання як у селі, так і в місті.

Висновок. Нова форма підготовки сімейних лікарів, що здійснюється у навчально-практичних центрах первинної медико-санітарної допомоги у сільській місцевості, дозволяє водночас перевірити та реалізувати набуті теоретичні знання й практичні навички та безпосередньо ознайомитись зі специфікою роботи сімейного лікаря у первинній ланці охорони здоров'я.

3. Навчально-практичні центри первинної медико-санітарної допомоги - нова форма підготовки сімейних лікарів / Л. Я. Ковальчук, В. Б. Гощинський, Л. С. Бабінець [та ін.] // Сімейна медицина. -2010. - № 3. - С. 23-24.

4. Навчально-практичні центри первинної медико-санітарної допомоги на селі. - Тернопіль : Укрмедкнига, 2012. $-32 \mathrm{c}$. 